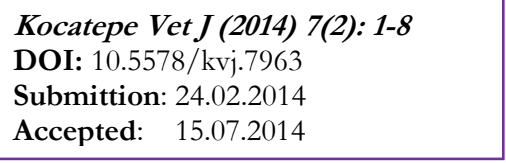

RESEARCH ARTICLE

ARAŞTIRMA MAKALESI

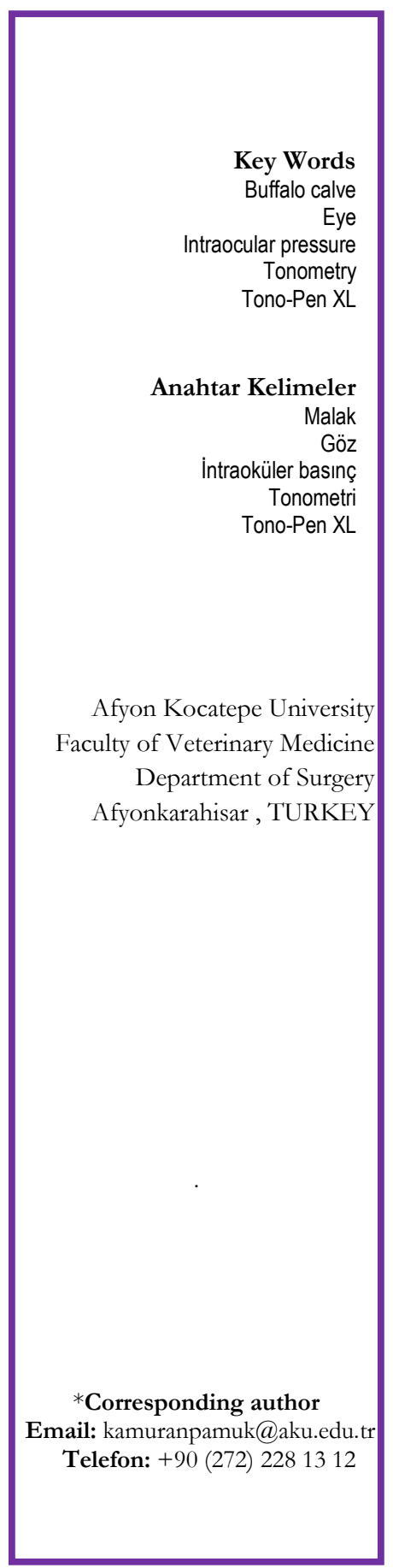

\section{Intraocular Pressure In Buffalo Calves}

\section{S U M M A R Y}

This study was carried out for the determination and the evaluation of intraocular pressure (IOP) in Anatolian Buffalo calve by means of applanation tonometry. A total of 78 eyes of 39 healthy Anatolian Buffalo calves aged between 1 and 11 months old from both sexes were examined. IOPs of Anatolian Buffalo calves were measured at the same time once in the morning on each eye during six month period every morning. IOP's of the left eyes were found to be $23,58 \pm 2,8 \mathrm{mmHg}$ (range 17,30-29,60 $\mathrm{mmHg}$ ) whereas the right eyes were 23,28 $\pm 3,28 \mathrm{mmHg}$ (range 17,30-30,60 $\mathrm{mmHg}$ ). Comparison of the tonometries between right and the left eyes of Anatolian Buffalo calves showed no significant difference, statistically. IOP was found to have no correlation to a decrease in concordance with the age of the animal. To our knowledge, this is the first report of tonometrical investigation performed in Anatolian Buffalo calve. The IOP for Anatolian Buffalo calves was determined as $23.43 \pm 2.8 \mathrm{mmHg}$.

\section{Malaklarda İntraokuler Basınç}

\section{ÖZET}

$\mathrm{Bu}$ çalışmada, Tono-Pen XL applanasyon tonometresi kullanılarak Anadolu malaklarında intraoküler basınçların belirlenmesi ve değerlendirmesi amaçlanmıştır. Çalışmada, yaşları 1-11 ay arasında değişen, değişik cinsiyette, sağlıklı 39 adet malağın 78 gözü değerlendirildi. Anadolu malaklarının intraokuler basınç (İOB)'ları her sabah aynı saatte aylık olarak ölçüldü. Sağ gözlerin İOB değerleri ortalama 23,28 $\pm 3,28 \mathrm{mmHg}$ (17,30-30,60 mmHg arasında), sol gözlerin İOB değerleri ise ortalama 23,58 $\pm 2,8$ $\mathrm{mmHg}(17,30-29,60 \mathrm{mmHg}$ arasında) bulundu. Anadolu malaklarında sağ ve sol göz IOOB’ları karşılaştırıldığında istatistiksel olarak önemli bir fark gözlenmedi. Yaşa bağlı olarak İOB değerlerinin azalmadığ1 görüldü. Yapılan literatür tarama sonucunda bu çalışmanın Anadolu malaklarında gerçekleştirilen ilk İOB değerlendirme çalışması

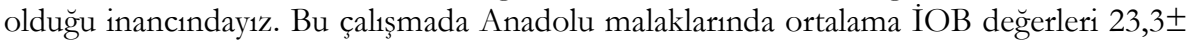
3,04 mmHg olarak belirlendi. 


\section{INTRODUCTION}

The ability to see is a complicated set of procedure for the gathering of lights around that is reflected from objects. Later, these light beams are converted into electrical signals by retinal cells and carried through nerves to the related locations of brain's stems for seeing (Ak1n and Samsar, 2005; Liebich et al., 2007; Miller, 2008).

One of the main structre of eye is humour aqueus (HA). This fluid consisted of $95 \%$ water and $2 \%$ sodium, chlorine, albumine, ascorbic acid and various electrolytes (Gum et al., 2007).

Physical structure of HA can be tought as cerebropinal fluid and supplied by the capillary veins at processus cilliaris. This fluid is responsible for the nutriton of lens at bulbus oculi and cornea, meanwhile sustaining the consistent IOP in the eye. This pressure supply an endurance and repletion. On the other hand, when HA produced more than needed, unless the excess part taken (resorbed at schlemm ducts), the IOP increases (Akin and Samsar, 2005; Noyan, 1989; Liebich et al., 2007).

The IOP is the balance between the production and resobtion of HA (Miller, 2008). Short term factors effecting IOP is found as daily changes, forced enclosure of eye lids, contraction of M. retractor bulbi, coughing or valsalva manuevr, sudden changes in blood pressure, heart rate, exercise/overtraining, change of position in body or head. The long term factors are ageing, race, hormones (Glukocorticoid, growth hormone, oestrogen, progesterone), obesity, sex and seasonal changes (Gum et al., 2007).

The tonometry is the measurement of the pressure of HA by indentation or applanation tonometry .

In this study, one of the applanation tonometry device which is regarded as safe, TonoPen XL was used for the evaluation of IOP in Water Buffalo Calves (WBC).

\section{MATERIAL AND METHODS}

\section{Material}

Study group consisted of 39 WBC raised in Afyon Kocatepe Üniversitesi Hayvan Araştırma Merkezi farm by varying sex and ageing between 110 months old in Afyon Kocatepe University Animal Health Research Hospital. Ethical issue was granted by the local ethical committee Afyon Kocatepe University local ethic commity registered under 243/2010= conventionally available for human medicine (Figure 1). (Tono-Pen XL, Medtronic Solan, USA).

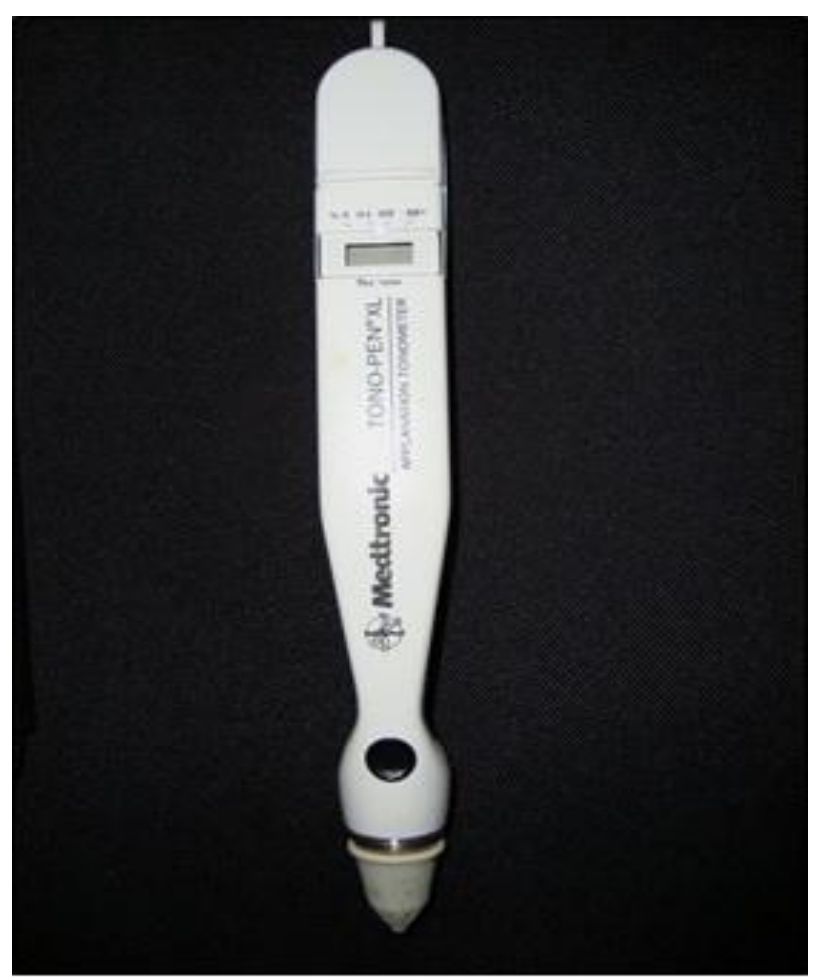

Figure 1. Tono-Pen XL tonometry

\section{Methods}

WBC are nervous for handling and a difficulty arises for gathering measurements from test subjects. Therefore prior to our study researchers accompanied to the care takers and calves were familiarized to the members by daily visits. Study cases were selected for the criterion; being free of any medication since 1 week before our study. Additionally, general health status of cases were investigated (Table 1). WBC were excluded according to their poor or overcachectic status. Eyes were examined for the existance of any type of disorders.

Eyes were colored with florocein dye for investigation of corneal damage and Schirmer-I test was used additionally. Eyes were excluded when absorbed the dye and gave value less than $15 \mathrm{~mm}$ in Schirmer-I test.

Animals were restrained and $0,5 \%$ proparacain $\mathrm{HCl}$ (Alcaine 0,5\% ophtalmic solution, Alcon pharmaceuticalis Ltd/ Alcon - Couvreur B2870 Puurs, Belgium) were administered to the eyes topically 5 minutes prior to measurement. (Figure 2). 
Table 1. The criteria of Health Parameters used in BC (Dalir-Naghadeh et al., 2006)

\begin{tabular}{|c|c|c|}
\hline Parameters & Healthy & Unhealthy \\
\hline Posture & Physiologic & Weak and Exhausted \\
\hline Temperament & Instant Responsive & Seduced \\
\hline Appetite & Good & Inappetent \\
\hline Body condition & Good & Cachectic - Weak \\
\hline $\begin{array}{l}\text { Body } \\
\text { Temperature }\left(\mathrm{C}^{0}\right)\end{array}$ & $38-39.5$ & Over 38-39.5 \\
\hline Fur Quality & Straight and Shiny & Opaque (pale), Disorderly \\
\hline Hearth Pace/min & $70-85$ & Over or under between values $70-85$ \\
\hline Mucosal Colors & Pinky & pale, anemic \\
\hline Feces quality & Dry and physiologic & watery, paste like, over dry \\
\hline Feces odor & Aromatic & Sharp and smelly odor \\
\hline Respiratory system & $\begin{array}{l}\text { No pathological sounds }- \text { normal inspiration, } \\
\text { expiration }\end{array}$ & $\begin{array}{l}\text { Coughing, tracheal and nasal respiratory } \\
\text { audible sounds }\end{array}$ \\
\hline Respiratory Rate/min & $12-28$ & Over or under the values $12-28$ \\
\hline
\end{tabular}

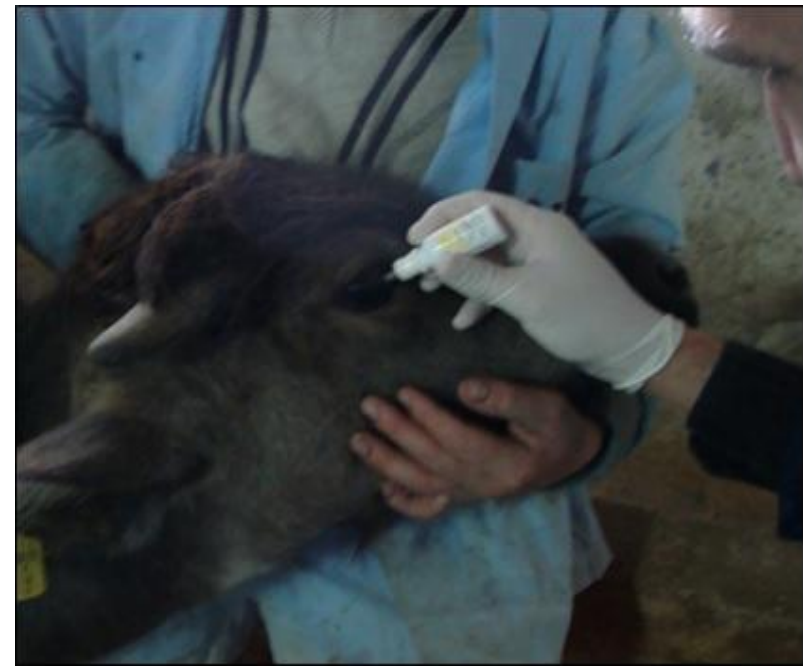

Figure 2. Topical drug administration.

IOPs were recorded with using Tono-Pen XL that was calibrated previously (Tono-Pen XL, Medtronic Solan, USA) (Figure 3) at 5 minutes after the application of the bull nose tool in all WBC. Latex cap was located onto tip of the Tonopen device and measurements were recorded three times from the center of cornea by holding device perpendicular to the surface. Then mean values of the three measurements were used for the eye (Figure 3).

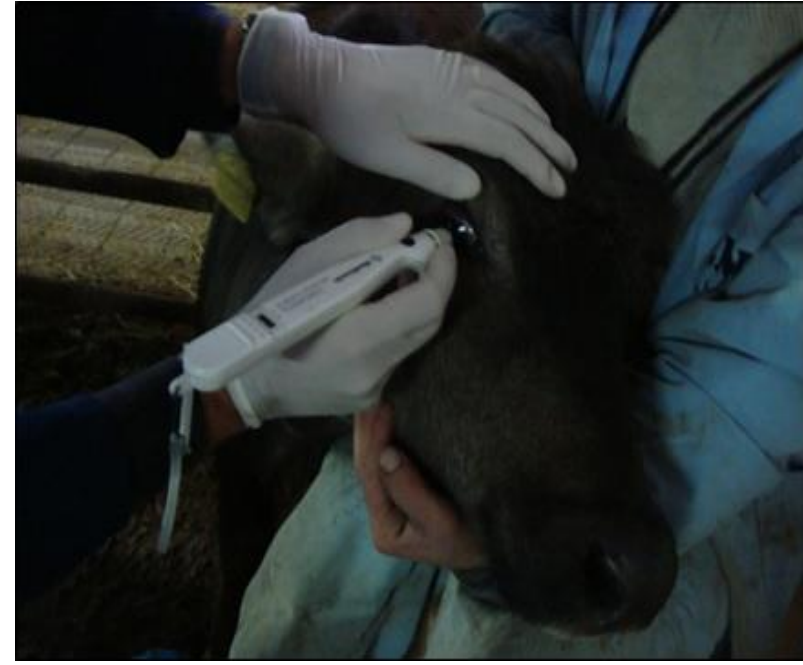

Figure 3. Tono-Pen XL tonometry IOP measurement.

\section{Statistical Analysis}

Wilcokon Signed Ranks, Oneway Anova, Univariate Analysis of Variance test were used for the statistical analysis. Data were shown as mean \pm standart deviation. The level of significance was set to $\mathrm{p}<0.05$ for the tests. 


\section{RESULTS}

All included subjects were tested montly for six months periods with Tono-Pen XL. In From February to July, right eyes mean IOP values were found as 23,63 $\pm 3,64 \mathrm{~mm} \mathrm{Hg}, 23,14 \pm 3,03 \mathrm{mmHg}$, 23,31 $\pm 3,32 \mathrm{~mm} \mathrm{Hg}, \quad 23,13 \pm 2,98 \mathrm{~mm} \mathrm{Hg}$,

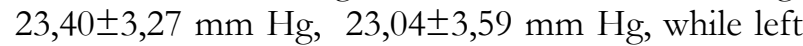

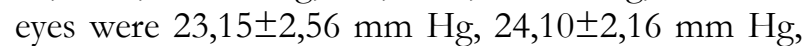

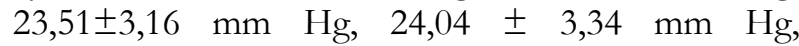
23,79 $\pm 2,73 \mathrm{~mm} \mathrm{Hg}, 22,86 \pm 2,80 \mathrm{~mm} \mathrm{Hg}$ (Table 2). Seasonal correlation to these values was found statistically insignificant ( $\mathrm{p}>0,05)$.

Females' right eye mean IOP was found as $23,44 \pm 3,49 \mathrm{~mm} \mathrm{Hg}$ while left eye was 23,63 $\pm 3,02$

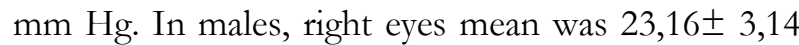
$\mathrm{mm} \mathrm{Hg}$ and left eyes mean was 23,54£2,69 mm Hg. However, these values were statistically insignificant $(\mathrm{p}>0,05)$.

In this study, the highest value for right side eye was found as $30,60 \mathrm{mmHg}$, and $29,30 \mathrm{mmHg}$ for the left, while the minimum was $17,30 \mathrm{mmHg}$ on the right and $17,30 \mathrm{~mm} \mathrm{Hg}$ on the left. Average IOP for right side was found as $23,28 \mathrm{mmH}$, while for left side the value was found as $23,58 \mathrm{mmHg}$.

In this study, the measured IOP values were found to be changing slightly during 6 months period however these changes were statistically insignificant for the difference $(p>0,05)$.

Table 2. Monthly distribution of IOP of WBC

\begin{tabular}{cccccc}
\hline Months & $\begin{array}{c}\text { Number } \\
\text { ofcase }\end{array}$ & $\begin{array}{c}\text { Mean IOP } \\
(\mathrm{mmHg}) \\
\text { Right eye }\end{array}$ & $\begin{array}{c}\text { Mean IOP } \\
(\mathrm{mmHg}) \\
\text { Left eye }\end{array}$ & $\begin{array}{c}\text { Maximum and } \\
\text { minimum values } \\
\text { (right eye, mmHg) }\end{array}$ & $\begin{array}{c}\text { Maximum and } \\
\text { minimum values } \\
\text { (left eye, mmHg) }\end{array}$ \\
\hline February & 39 & $23,63 \pm 3,64$ & $23,15 \pm 2,56$ & $18,00-29,60$ & $18,60-27,60$ \\
\hline March & 39 & $23,14 \pm 3,03$ & $24,10 \pm 2,16$ & $18,30-30,00$ & $19,60-29,00$ \\
\hline April & 39 & $23,31 \pm 3,32$ & $23,51 \pm 3,16$ & $18,30-30,60$ & $18,60-29,60$ \\
\hline May & 39 & $23,13 \pm 2,98$ & $24,04 \pm 3,34$ & $18,30-29,30$ & $18,30-29,30$ \\
\hline June & 39 & $23,40 \pm 3,27$ & $23,79 \pm 2,73$ & $17,60-29,60$ & $18,30-29,30$ \\
\hline July & 39 & $23,04 \pm 3,59$ & $22,86 \pm 2,80$ & $17,30-29,30$ & $17,30-28,60$ \\
\hline
\end{tabular}

\section{DISCUSSION}

In this study, 39 anatolian WBC, aging between 1-11 months from Afyon Kocatepe Üniversitesi Hayvan Araştırma Merkezi farm were used. All cases were evaluated for IOP during 6 months period using Tono-Pen XL.

There is no study found that document IOP in WBC in the literature. In a study conducted over 1059 water buffaloes, the mean minimal and maximal values IOP s were found as $16,50 \mathrm{mmHg}$ and 27,30 $\mathrm{mmHg}$, respectively (Pamuk et al., 2011).

Tonometry is the measurement of IOP andvarious methods have been utilized to measure the IOP. The widely used tonometers are applanation and indentation tonometers. Today, schiotz tonometer is used as indentation, and TonoPen-XL is used as applanation tonometer (Ak1n and Samsar, 2005).

There are differences between indentation and applanation tonometers. The usage of Schiotz tonometer is difficult. Application should be done on lateral recumbent or sitting patient. While using, the device should be centered on the eye horizontally and third eyelid should be deflected over the eye bulb. Due to contraction of extraocular muscles of eye IOP may change. The application tip of the device is adjusted for the human usage with $15 \mathrm{~mm}$ convexity. However, animals have wider angle in their cornea. The scleral rigidity vary between the animal species aslarger races have lesser IOP compared to smaller races (Ak1n and Samsar, 2005). An applanation tonometer, The usage of tonopen is widely accepted in large animal practice. Tonopen is not effected by anatomical variations in the eye. Conversion table and sterilisation is not needed (results are shown in $\mathrm{mmHg}$ ). The position of the head of the animal is unimportant. The probe of the device should be applied to the corneal surface perpendicularly (Maggs, 2008), with the latex protector cap to prevent contamination of eyes 
between individuals (Ollivier et al., 2007).

Tono-Pen XL application is easy and safe therefore we used Tono-Pen XL for the measurements. No difficulty was experienced during applications. Tono-Pen XL supplied a safe and problem free IOP measurements even in aggresive WBC. It was confirmed in previous studies that Tono-Pen XL is a non-invasive tool for the measurement of IOP and can be used in various breeds (Gum et al., 1998; Passaglia et al., 2004; Gellat and Mac Kay 1998).

There are several factors that effects the IOP. These are diurnal variation, race, heredity, exercising, postural changes, drugs, eye movements, blood pressure, ocular inflammations and seasonal changes (Gum et al., 2007).

In various breeds, IOP changes in day time. In the mornings the level is high whereas during day, the IOP level decreases in dogs and humans (Miller, 2008). Many individual has highest IOP until midday and the lowest pressure between night till morning. However, in some, between midday till evening the IOP makes a peak and has diurnal variation with varying values inconsistent within the day time (Hoskins and Kass, 1989; Kitazawa and Horie, 1975). In humans, IOP changes during day time and the reason is still unknown. The plasma cortisol levels are said to be effective in this purpose. Distinct from some others, some of individuals have rising IOP at after the midday of to the night. (Tiğ, 2006).

In our study, the level of IOP were gathered by the same researcher in the morning time therefore the chance of getting data with bias was eliminated and the values were more confidential .

Glaucome (GA) is reported in large ruminant to be less than $1 \%$. In Italy, 500 dairy cows examined and congenitally seconder GA had been determined (Townsend, 2008). Cats are found to be less susceptible for GA than dogs, except for siamese, persian, european short hair, burmese races (Stiles and Townsend 2008). In another study (15 Holstein, 12 Jersey) with Mackay-marg and Tonopen XL were reused and mean values were found as $28,2 \pm 4,6$ $\mathrm{mmHg}$ (between 19-39 $\mathrm{mmHg}$ ) and 26,9 \pm 6,7 $\mathrm{mmHg}$ (between $16-42 \mathrm{mmHg}$ ) respectively (Gum et al.,1998).

In a study for hereditary evaluation, open angled GA was found as more frequent in first degree relatives (Hoskins and Kass, 1989). Genetically, GA formation in wild dogs is reported in old ages. In this race the feature of GA is seen to be carried by an autosomal recessive genes (Brooks, 1990; Gelatt, 1999).
In this study, only WBC were used therefore race factor was eliminated in the research. As genetic background of animals were unknown, the genetic parameters were not evaluated.

The IOP rises when animals are forced to exercise. In a study conducted on 26 dogs, IOP pressure was measured after thedogs were forced to run/walk with the leash pressurized to their neck the neck thereafter the IOP was found to be increased compared to previous state (Pauli et al., 2006; Miller, 2008 ). In continuance, IOP may rise or fall according to the type of the exercise. As an example, it was reported that, over-exercising in humans decreased the IOP by $24 \%$ as the mean value for the cases with healthy eye and 30\% in the cases with open angled GA (Aksakal, 1993).

Postural variations effects the IOP, also. In one of the human study, the change of position from sitting to lying changes IOP by $0,3-0,6$ $\mathrm{mmHg}$ in the eyes (Coşkun, 2001).The sytemic hypertension increases the IOP by resting the patient at dorsal recumbency position for 15 minutes when compared to normal blood tension cases (Aksakal, 1993).

In this study, IOP measurements were gathered while $\mathrm{WBC}$ were at resting state on foot. IOPs were recorded 5 minutes after the application of the bull nose tool to their nose in all WBC. Stress was decreased within this period of time. Moreover, animals were controlled at the same fashion to reduce bias between measurements.

Drugs can effect IOP. While various anesthetics and tranquilizers decreases IOP, on the other hand ketamine increases IOP temporarily (Miller, 2008). Glucocorticoids increases the IOP in humans. The reason the increase is explained by the topically administered steroids yields the accumulation of dihydro cotisole in trabecular cells abnormally by dislocating the glucocorticoid receptors in adjacent corneoscleral and in iris cilliary bodies (Akyol and Turgut, 2006). It is reported that, ocular hipertension could be produced when prednisolone acetate applied 3 times a day to healthy cows eyes(Townsend, 2008). Mannitol 10- 20\% is an osmotic diuretic solution. When applied intravenously at the dosage of $1-2 \mathrm{~g} / \mathrm{kg}$ IOP decreases in 20 minutes (Renwick and PetersenJones, 2009). In several studies some of the anesthetic solutions are reported to effect IOP (Pamuk, 2003; Ausincch et al., 1977; Al-Abrak and Samuel, 1974).

In this study, WBC that were free of one week of any medication were selected due to any effect to IOP. Moreover none of any systemic anesthetic medication was applied prior to measurements only 
but local \% 0,5'lik proparacain $\mathrm{HCl}$ used topically. By using topical anesthesia ocular pulsation was eliminated and confidential data were gathered.

In a study with humans, the eye blinking was found to increase the IOP by $10 \mathrm{mmHg}$. However, eye blinking of the patients with GA decreases IOP slighty. Moreover, when the eyes are closed tightly IOP may rise up to $90 \mathrm{mmHg}$ (Coşkun, 2001).

In our study, the eyelids were hold by a helper during measurements and eye blinkings were prevented for accurate measurements. The most important feature of applanation tonometry is the possibility of getting meaurements from any part of cornea therefore prevention of the third eyelid was not needed in our study. Moreover, the measurement took less than 5 seconds thats why none of eye blinking problems were encountered.

In a recent study the low blood pressure (as like dehydration, hypovolemic shock, cardiogenic shock) was reported be the cause of low IOP (Miller,2008). The arterial pressure changes within cardiac cycle effects the IOP within $1-3 \mathrm{mmHg}$. As known before, the increase in IOP may depend on the arterial pressure changes (Hoskins and Kass, 1989).

Ocular inflammation is reported to effect the IOP. Spontaneous or post surgical interventions and uveitis decreases the production of humour aqueus therefore IOP level decreases(Miller, 2008).

None of the WBC was found to have eye disease at the beginning of our study. As this study was held as a field work invasive blood pressures were not measured for the comparison. As this parameter is tought to effect IOP, new studies must be utilized with regarding reference values.

Ageing decreases humor aqueus productions and excreations. It is reported that in human and animals, IOP decreases with age. Especially in cats after 7 years old, every year the IOP level decreases by $1 \mathrm{mmHg}$ (Miller, 2008). On contrary to this, in some human researches, it was reported that a positive correlation was found between IOP and ageing. The IOP increases in humans especially after 40 years old (Hoskins and Kass, 1989). In some literature, IOP was reported to increase within increasing age and secondarily, pulse frequency, obesity, and increase in blood pressure effects over (Carel et al., 1984). In a study conducted with a total of 1059 water buffalo, 216 of cases over 1 years old was found to have a mean IOP of $22,55 \pm 0,18$ $\mathrm{mmHg}$ in right eye, and $22,54 \pm 0,18 \mathrm{mmHg}$ in left eye. 17 waterbufalo at 8 years old was found to have a mean IOP of $21,93 \pm 0,64 \mathrm{mmHg}$ in right eye, 21,97 $\pm 0,64 \mathrm{mmHg}$ in left eye (Pamuk et al., 2011).
In this study, 2 animals ageing 1 months old had mean IOP of $22,30 \pm 1,41 \mathrm{mmHg}$ in the right eyes, $24,45 \pm 0,21 \mathrm{mmHg}$ in the left eyes. $10 \mathrm{WBC}$ aging 10 months was found to have IOP mean of $23,05 \pm 3,93 \mathrm{mmHg}$ in the right eyes, and 22,42 $\pm 2,33$ $\mathrm{mmHg}$ in the left eyes. In a case aged 11 months the right eye mean was found as $24,30 \mathrm{mmHg}$, while left was $17,30 \mathrm{mmHg}$. The evaluation of age effect on the IOP gave no significant result in this study.

The gender effect on IOP has been evaluated in humans and IOP was found higher in women (Aksakal, 1993). In another study, no correlation were reported between gender and IOP (Hoskins and Kass, 1989).

In our study, the mean of IOP in right eyes was found as $23,44 \pm 3,49 \mathrm{mmHg}$, while left was $23,63 \pm 3,02 \mathrm{mmHg}$. In males, the mean in right side was found as $23,16 \pm 3,14 \mathrm{mmHg}$, while mean value for the left eyeswas $23,54 \pm 2,69 \mathrm{mmHg}$. There was no significant difference between males and females in our study $(\mathrm{p}>0,05)$.

The seasonal effect on IOP is due to duration of the day light therefore intra ocular pressure is higher in winter than the summer (Hoskins and Kass, 1989).

In our study, the mean IOP's in February was found as $23,63 \pm 3,6 \mathrm{mmHg}$ for right side, and $23,15 \pm 2,5 \mathrm{mmHg}$ for the left, however in July the right sides were $23,04 \pm 3,5 \mathrm{mmHg}$, and left sides were $22,86 \pm 2,8 \mathrm{mmHg}$. There was no statistically significant correlation with seasonal change and IOP in our study $(\mathrm{p}>0,05)$.

In a study with water buffaloes, the minimum pressure values were found as $16,10 \mathrm{mmHg}$ on right eyes and $16,50 \mathrm{mmHg}$ on the left eyes. The maximum values on the left side was $27,30 \mathrm{mmHg}$, and $27,00 \mathrm{mmHg}$ on the right. Average IOP was found as 22,06 $\pm 2,68 \mathrm{mmHg}$ (Pamuk et al., 2011). In this study, right eyes' minimum was $17,30 \mathrm{mmHg}$, and the maximum was $30,60 \mathrm{mmHg}$, and for the left eye the minimum was $17,30 \mathrm{mmHg}$ and maximum was $29,60 \mathrm{mmHg}$. Our study values were found to be similar to the previous study with buffaloes.

\section{CONCLUSION}

In conclusion Tonopen XL tonometer was found to be as easy and also rapid diagnostic tool for the measurement of IOP confidentially. Moreover the IOP reference values for WBC were 23,28 $\mathrm{mmHg}$ for right eye, and 23,58 $\mathrm{mmHg}$ for the left eye. Evaluation of the parameters effecting IOP within these reference values were found to be more convenient and confidential. The data evaluated within this study elucidates future studies and clinicians for daily practice. 


\section{REFERENCES}

Akın F, Samsar E. Göz hastalıkları, Medipres Matbaacilık LTD. ŞTİ. 2005.Malatya

Aksakal F. Schiotz, Goldmann applanasyon and keler pulsair non kontakt tonometreler ile miyop, hipermetrop and emetrop gözlerde göz içi basınçlarının ölçümlerinin karșılaştırılması. 1993.T.C. S.S.K Okmeydanı Hastanesi Göz Hasta. Klin. Uzmanlık Tezi.

Akyol N, Turgut B. Steroid Glokomu. GloKat.2006; 1: 239- 244.

Al-Abrak MH, Samuel JR. Further Observations on the Effects of General Anaestesia on Intraocular Presure in Man : Halothane in Nitros Oxide and Oxygen. Br. Jour. Of Anaest.1974; 46: 756-759.

Ausinsch B, Munson ES, Levy NS. İntraocular pressures in children with glaucoma during halothane anesthesia. Ann. Ophthalmol.1977; 9(11): 1391-1394.

Brooks DE. Glaucoma in the dog and cat. Vet. Clin. N. Amer. Small Animal Prac. 1990; 20 : 775797.

Carel RS, Korczyn AD, Rock M, Goya I. Association between ocular pressure and certain health parameters. Ophthalmology. 1984; 91 : 311- 314 .

CoşkunM.http://tip.erciyes.edu.tr/Anabilim/Cerra hi/Web/Goz_Hastaliklari/Mesut\%20Coskun \%20SON. 2001; htmerişim tarihi: 11.09.2010

Gelatt KN, Mac Kay EO. Distribution of Intraocular Pressure in Dogs. Veterinary Ophthalmology.1998; 1: 109-114.

Gum GG, Gelatt KN, Miller DN, Mackay EO. Intraocular pressure in normal dairy cattle. Veterinary Ophthalmology.1999; 1: 159-161.

Gum GG, Gelatt KN, Esson DW. Physiology of the Eye In: Fourth Edition Veterinary Ophthalmology ed: Gelatt K N. Blackwell Publishing Ltd. 2121 State Avenue, Ames.,Iowa 50014, USA. 2007; 4: 1592-1593

Hoskins HD, Kass MA. Becker - Shaffer's Diagnosis and Therapy of the Glaucomas 6th edition.1989; The C: V : Mosby Comp's pp:60-63

Kitazawa Y, Horie T. Diurnal Variation of İntraoculer Pressure in Primay Open - Angle Glaucoma. Am. J. Ophthalmology.1975; 79: 557-560.

Liebich HG, König HE. Eye (organum Visus).
In: Veterinary Anatomy of Domestic Mammals: Textbook and Colour Atlas. 3rd. Edition. ed: König H.E, Liebich H.G Schattauer GmbH, Germany. 2007; pp. 571608.

Maggs DJ. Cornea and Sclera, İn: Slatter's Fundamentals of Veterinary Ophtalmology , Edition 4. ed; Maggs, J. D, Miller, E.P, Ofri, R. Saunders Elsevier 11830 Westline Industrial Drive St, Louis, Missouri 63146.2008; pp. 175-201.

Miller PE. Structure and Function of the Eye, Slatter's Fundamentals of Veterinary Ophtalmology, Edition 4. ed; Maggs, J. D, Miller, E.P, Ofri, R. Saunders Elsevier 11830 Westline Industrial Drive St, Louis, Missouri 63146.2008; pp. 1-19.

Moses RA, Hart WM. Adler's Physiology of the Eye. $8^{\text {th }}$ edition. The C. V. Mosby Com 1987; pp: 373-375

Noyan A. Özel Duyular, Görme Duyusu. İn: Fizyoloji Ders kitabı (6.basım). Ed: Noyan, A. Meteksan A.Ş.1989; sy.421- 463.

Ollivier FJ, Pulummer CE, Barrie KP.(2007). Ophthalmic Examination and Diagnostics, İn: Fourth Edition Veterinary Ophthalmology ed: Gelatt K N. Blackwell Publishing Ltd. 2121 State Avenue, Ames.,Iowa 50014, USA.2007; pp: $438-476$.

Pamuk K. Köpeklerde Halotan and İzofloran Anestezisinin İntraoküler Basinca Etkisinin Karşılaştırılması. Ankara Üniversitesi Sağlık Bilimleri Enstitüsü. Cerrahi Anabilim Dalı Doktora Tezi. 2003.

Pamuk K, Sarıtaş ZK, Demirkan İ, Acar A, Korkmaz M, Acar DB. Animal Welfare related to evaluate Intraocular Pressure in Anatolian Buffaloes; Preliminary report. Journal of Veterinary and Animal Advances.2011; 10 (8) 987-990.

Passaglia CL, Guo X, Chen J, Troy JB. TonoPen XL calibration curves for cats, cows and sheep. Veterinary Ophthalmology. 2004; 4: 261- 264. PMID :15200622.

Pauli AM, Bentley E, Diehl KA, Miller PE. Effects of the Application of Neck Pressure by a Collar or Harness on Intraocular Pressure in Dogs. J Am Anim Hosp. Assoc. 2006; 42: pp:207-211.

Renwick PW, Petersen-Jones SM. Orbital and Ocular Pain, İn: Small Animal Ophthalmology a Problem - Oriented Approach. ed: Peiffer, 
R., Jones-Petersen, S. Elsevier Limited. 2009; pp: 203-249.

Rezaei SA, Naghadeh BD. Evaluation of antioxidant status and oxidative stress in cattle naturally infected with Theileria annulata, Veterinary parasitology 2006;142(1-2):179-86.

Stiles JT, Townsend WM. Feline Ophthalmology. İn: Essentials of Veterinary Ophthalmology. Ed: Gelatt, N. K. Blackwell publishing Professional 2121 State Avenue, Ames, Iowa 50014 USA.2008; Sy. 293-330.

T1ğ UŞ. Göz İçi Basınç Ölçümünde Hata Kaynaklar1, S.D.Ü Tip Fakültesi Dergisi.2006; 13 (3): 32-35.

Townsend WM. Food and Fiber - Producing Animal Ophthalmology In: Essentials of Veterinary Ophthalmology 2nd Ed., Gelatt K. N. Blackwel Publishing Professional 2121 State Avenue, Ames, Iowa 50014 USA.2008; pp: 379-381. 